\title{
DR. BUTLER REVISITED
}

by

\section{VIVIAN NUTTON*}

William Butler, Fellow of Clare College, Cambridge, was famous in his lifetime as a medical eccentric, whose practice could only with difficulty be classified under any school-theory. His papers, preserved in the Fellows' Library at Clare, confirm that he was humane and forthright, not tied to any philosophical system but with ideas pointing towards the testing of remedies by trials and of theories by experience. Such is the just verdict of Dr. Jeffrey Boss in his recent publication in this journal of seven of the Butler Mss., ${ }^{1}$ but his implication that they are all that remains in them of medical interest is far from true. In this article I shall deal first with four other pieces from that collection, all in Latin, which throw light on Butler and contemporary medicine; and secondly offer some corrections and elucidations of the published documents, also thereby showing the range and character of Butler's learning. ${ }^{2}$

I

For all his fame as a doctor, Butler's medical expertise and qualifications were doubted by the Royal College of Physicians, who licensed him to practice only after a letter from Lord Burghley and even then under restrictions. ${ }^{3}$ His bitter view of the College is evident from a letter published by Dr. Boss, p. 444, and in a rambling and allusive Latin reply (Ms. 39) to an anonymous academic physician he reveals a similarly jaundiced attitude at the end of his life towards medicine and its practitioners in general. The translation is as follows:

Venerable doctor, your letter to me gave me great pleasure: I recognize in it your wisdom, the candour of your noble heart, the virtue and consummate skill of your medical practice, and the rashness and inconstancy of the noble lady with you. Woman, to use the words of the poet, " is always fickle and changeable, and always immoderate: for she loves too much and hates

*Vivian Nutton, M.A., Ph.D., Wellcome Institute for the History of Medicine, 183 Euston Road, London NW1 2BP.

$1 \mathrm{~J}$. Boss, 'William Butler (1535-1618), further evidence on a physician between two ages', Med. Hist., 1977, 21 : 434-445.

2 I am grateful to Dr. D. J. Crawford and Dr. P. G. Lowe for their assistance, and to the Master and Fellows of Clare for permission to publish these documents. Butler's script, especially when written hurriedly, is not easy to read, and I have not bothered to correct such minor errors in Dr. Boss's transcription as do not affect the sense. Future investigators should perhaps be warned that the incomplete transcripts and versions kept with the papers are not always accurate.

- G. N. Clark, A history of the Royal College of Physicians of London, Oxford, Clarendon Press, 1964, vol. 1, p. 140. A letter of 1600 by Robert Cecil to Butler, incidentally praising his talents, is also preserved among the papers (Ms. 28).

- Vergil, Aeneid IV 569: the Greek quotation that follows does not come from Euripides but may be a free composition based on e.g. Medea 263, or Melanippe, fr. 494,

Nothing is more evil than an evil woman,

Nought but a good one's so supremely good,

So different are her natures. 


\section{Vivian Nutton}

to excess, as Euripides says. You have no reason to be afraid that false rumours are dispersed and scattered abroad among the people, as you fear; for just as we see bubbles stirred up by the wind suddenly swell and in a brief moment strike against stones and burst, so these empty lies, since by design they are light, blown along up in the air and filled with nothing, suddenly fly away like vapours and vanish, and all their fictions drop swiftly like tiny flowers. The common people is a many-headed beast, a monster full of vanity and error, mere folly and prating ignorance which no wise man fears. I should be very angry and bitter at any violation of your dignity, which ought to be safeguarded and to be honoured and respected especially by those who, being raised up by you, have obtained through your health-giving precepts the ripest fruits of sound living and a healthy life. For my part, I have tried to defend your honour and reputation: and though my strength was unequal to it, yet, instead of my weak powers, I shall transmit my good will to you. Of the other masters and leaders of medicine I shall say no more: would that I had no cause for just complaint! If they knew me, they would not spew forth the venom of their bitterness so unworthily and maliciously (1), and would not smear such muck on my name, or brand me with infamy. Slander is the very viper of fame and life. As the divine Scaliger says," such is the life of men. For each one of us relying on himself, takes each step towards his own glory by ruining another's name. Therefore, by withdrawing into myself, I have proposed for myself another kind of life, and have begun to consider as well as the envy and spleen (which has always been a very faithful Achates to my actions), ${ }^{6}$ how delicate, uncertain, treacherous, slippery, and deceitful the practice of medicine is. For since Galen set out these three categories, " knowledge, ignorance and skilful conjecture (2), and since medicine is neither knowledge [episteme], nor ignorance [agnoia] but only the conjectural power [Stochastice dynamis] left in the middle and is entirely at the mercy of the judgment and calculations of men, it thus follows that doctors are soothsayers, diviners, forecasters, and hypothesizers, and produce hallucinatory prophecies, and often mistake falsehood for truth. This state of affairs has so deterred me, who was otherwise quite eager for the discipline, that it has entirely converted me to a truer and more certain kind of philosophizing: and, to put it frankly, it now absorbs me almost entirely. I am not the sort of man to find the be-all and end-all of my studies in medicine, which is the servant of pride (3), the bringer-forth of lasciviousness, the nurse of delusions, the mistress of dyes and bodily beauty, the handmaid of wealth and fortune, the daughter of toil, the child of grief, an offspring in captivity, a mercenary virtue trailing after servitude, and envious of the bronze-smith's art: for I now burn with desire for a higher philosophy and am carried along by a great surge, though my days are already short and drawing to an end, and old age bears heavy upon me. After many stormy cures, and very many exhausting and debilitating labours, anxieties of the soul and manifold torments of the mind, on my second voyage, by the favour of a divine power and by a heavenly inspiration, I have found a better fortune and repose among pleasanter muses as in a haven of rest and comfort. So to participate in politics, to use chicanery, the peculiar virtue of courtiers, to be steeped in the habits of Etruria, and to be infatuated with cleverness, to hate another's virtue, to flatter the people's ear, to cast darkness over even the brightest light, this I think not only inhuman but savage and bestial, so that not without reason (as Caesar agreed) are deceit and treachery called the plague of friends and the cancer of the heart.' Farewell, most learned Sir, and be assured that none is dearer to me than you. Ever most zealous for your dignity.

Pray, give my regards to our most honoured Henry.

\section{W. Butler}

- J. C. Scaliger (1484-1558) is now known only for his son, J. J. Scaliger (1540-1609), the great Classical scholar, but in his time he was famous as a critic, doctor, and scientist. His longest work, Exotericarum exercitationum liber $X V$ de subtilitate, Paris, 1557, and four times reprinted, is a rambling and diffuse attack on Cardan, more impressive for the variety of its learning and the vigour of its polemic than for the sophistication and logic of its argument. It was a favourite of Butler's, to judge from his several citations of it. Here he alludes to ch. 33.1, where Scaliger argues that men are far more vicious in their habits than any viper, and by their venom destroy all that is good in life.

- Achates was the devoted companion of Aeneas.

'This triple division is found in a work ascribed to Galen 'Introduction', XIV $685 \mathrm{~K}$ : Galenic support for seeing medicine as a conjectural art occurs in his Commentary on Hippocrates' Aphorisms, I.1 and I.12=XVIIB 348-9 and $382 \mathrm{~K}$, but note, by contrast, his view at XII $546 \mathrm{~K}$.

- The Etruscans invented the art of acting, according to Livy, History of Rome, VII.2.

- Possibly an allusion to Suetonius, Life of Augustus, 65, where Augustus called his deceitful relatives "plagues and cancer". 


\section{Dr. Butler revisited}

In the margin are the following notes:

(1) It is a disgraceful race of men who are wont to make clear their own filth by the severity of their censure of others.

(2) Hippocrates, On internal diseases: opinion more than skill decides these matters. ${ }^{10}$

(3) Unhappy virtue, you were thus an empty name. Yet I worshipped you as something firm, though you were all the time the slave of fortune.

The second document (Ms. 25) is a brisk response in Latin to an enquiry on a variety of topics: the translation runs:

My dear sir, you would gladly inquire about habits of study, about wine, an aromatic cap, salt of euphrasy, and gargles.

First, on arising from sleep, let there be a slight evacuation of the bowels, then one should use the space of one hour to banish the vapours which, begotten in the night time, with nature as stepmother, dull and cloud the brain with darkness: then you should busy yourself with your studies in the morning until lunch, but each hour have a small break to relax the mind: for concentration on studies blunts and oppresses the animal spirits.

One should avoid full-blooded wines such as Spanish Falernian, ${ }^{11}$ Malmsey, and the like, which go to the head and stuff and fill it thick with fumes: lighter wines can be allowed, such as the thinner whites like those of the Rhineland. Morever at dinner wine is forbidden.

A head-cap ${ }^{12}$ properly made from different varieties strengthens a cold brain, but oil of nutmeg, flowers of sage, and cloves are more beneficial if they are rubbed quite often on forehead and temples.

Salt of euphrasy ${ }^{12}$ has a wonderful effect on the brain by its secret power and sharpens a dulled vision if skilfully prepared: but medicated wine concocted from flowers of euphrasy holds first place.

Let a family gargle be prepared from mustard, a very pungent perry vinegar, and a very great deal of honey to prevent skinning of the flesh. Then, as for your diet, I advise you to use entirely plain food, very juicy and easily digestible, like the flesh of sheep, goats, heifers in milk, partridges, persian peacocks, young chickens, rabbits, young hares, pigeons, and mountain birds, which (as Aristotle agrees) ${ }^{16}$ is easily digested and distributed and produces pure blood.

Finally, to sum up, one should have recourse to Cicero médecin des mots, whose precept should be followed:

Health is preserved by a knowledge of one's body. ${ }^{15}$

The third piece of medical interest is a eulogy of Butler by William Gager, an Oxford poet and Chancellor to the Diocese of Ely from 1606 to $1619 .{ }^{16}$
Nota triplex medici facies est: una rogati,
Altera sanantis, poscentis tertia munus.
Angelus apparet primâ, Deus ipse secundâ.
Postrema Daemon: tres hos tria tempora vultus
Attingunt medico, totidem tibi sunt quoque formae,
Osque triplex Butlere tibi est clarissime, tantum

${ }^{10}$ Cf. Hippocrates, On diseases, I; VI, p. 142 L: On places in man, 1; VI, p. 330 L.

11 Sherry? or port? or should the punctuation be changed to give "Falernian, Spanish, Malmsey ..."?

12 On aromatic caps, cf. J. Heurnius, Praxis medicinae nova ratio, ed. 2, Leyden, 1609, pp. 60-61.

12 See W. F. Daems, 'Bijdrage tot de Geschiedenis van Euphrasia', Scientiarum Historia, 1962, 4: 53-63.

14 Possibly a conflation of On parts of animals, II, 651a, 20-36, with Nic. Eth., VI, 1141a 18-21: all these examples of proper foods can be found in Galen's On the preservation of health and On the properties of foods.

${ }^{16}$ Cicero, On duties, II, 86.

16 Dictionary of national biography, vol. 7, pp. 797-798. 


\section{Vivian Nutton}

Hoc aliis praestas medicis discrimine, quod tu

Posteriore nites ${ }^{17}$ aeque, nec quando rogaris

Nec, quando sanas, facies tibi pulchrior ulla est,

Quam cum mercedem curato respuis aegro,

Magnanimus contemptor opum Croesusque videris

Non capiendo aliis, vere es tibi, non cupiendo.

Est tibi cum multis communis prima, secunda

Cum paucis, sola est tua tertia; quâ dum

Rem tractas medicam, quasi rex, es rex medicorum.

Ergo tu (quicunque illis videare duabus

Angelus et deus, ut sis) hâc verus mihi rex es.

The triple face of the doctor is well known: he has one when consulted, another when healing, the third when asking his fee. He seems an angel in the first aspect, god himself in the second, and a demon in the third: three moments bring these three appearances to the doctor, and you also have as many forms, and you too, most famous Butler, have a three-fold countenance. You are superior to the other doctors only in this regard, that you are equally splendid in your last, and neither when you are consulted nor when you are healing is your appearance more beautiful than when you reject the fee from a cured patient. You seem a noble despiser of wealth and a Croesus by not taking it from others, and you are so in truth by not desiring it for yourself. The first countenance you share with many, the second with few, yours alone is the third: by virtue of which, even as you practise medicine like a king, are you the king of doctors.

So, whatever angel or god you may appear to be in your first two aspects, by this last you are my true king.

With this may be compared an anonymous Latin poem, preserved among the papers:

Qui venis huc peregre, quidquid hac in pyxide clausum est. antidotum

Exigis, unguentum nomine Butler inest.

Hic certam posses olim sperare salutem

Nunc languet serio cassa medela suo:

Tanta tamen remanet virtus, ut lumine laesus,

Hos tangens lapides, posset abire videns;

Ni dolor et lachrymae pro tanti morte fluentes

Plus noceant, saxum quem reparare queat.

Whoever comes here in suffering, raise up the contents of this box, an ointment is within, antidote

called Butler. Here you could once hope for sure relief, now his cure languishes, frustrated by its own old age. Yet such power remains that a man with defective vision touching these stones could go away and see: unless the grief and tears flowing for the death of such a great man caused more harm than the stone could restore. ${ }^{18}$

\section{II}

A Renaissance doctor was expected to display the flowers of his learning both as impressive evidence of his superior culture and as persuasive authority for the truth or effectiveness of his statements and therapy. The piling-up of allusions and references to the Bible, classical authors, and medical men, was for a purpose, partly demanded by the academic conditions of the time and partly for practical ends. ${ }^{19}$ In controversy-and Butler was a vigorous controversialist-to suggest that one's own opinion was shared with past masters like Scaliger or Galen was at one and the

17 What Gager first wrote here is unclear, possibly "micas".

18 Although this poem deals with Butler's tomb, it is not his formal epitaph, for which see $J$. Aubrey, Brief lives, edited by Andrew A. Clark, Oxford, Clarendon Press, 1898, p. 142.

${ }^{10}$ It is very unlikely that any of the three quotations noted by Dr. Boss, p. 439, n. 42, involved facetiousness. 


\section{Dr. Butler revisited}

same time to increase its weight and to remove some of the personal acerbity of an unsupported assertion. I have not endeavoured to track down all the springs of Butler's learning, but I hope that those I have discovered will suffice to illustrate his academic methods and attainments.

*436, n. 19. The psalm sayeth: Psalm 131, 1 in the Prayer Book version.

436, n. 22. Habet ... in est: Read inest, and translate: "Even the fly has spleen, and the ant has its own bile within."

436, n. 23. Nemo-suae: Read invidet, and translate: "No-one envies another virtue who is confident enough of his own."

436, n. 24. The quotation from Scaliger, deliberately and exactly given, is to his Exotericarum Exercitationum Liber XV, Paris, 1557: translate, "I speak by my own lights barbarously and in the Oxford manner, not from platforms and parliaments." Scaliger is here saying that he is not giving an elegant formal address in public, but reverting to a medieval, non-Ciceronian philosophical jargon: "That the receptive does not receive by means of the impressor but by means of receptivity is untrue."

436, n. 25. "Theft is the taking of another's property against its master's will [invito]"-a simple definition from Roman Law, see Aulus Gellius, XI.18.20; Codex Justiniani, 6.2.20.1; Gaius, Institutes, $195 \mathrm{ff}$.

437, n. 27. Filistus: "Philistus, an insolent critic and an envious censor of learning [disciplinae] used to reprove the words and deeds of all ...."

437, n. 28. Galen: Commentary on Hippocrates 'On humours' 1.7, (XVI, p. 81, ed. Kühn). It is ironic that this passage comes from a Renaissance forgery, assumed by Butler and many others to be genuine, but parallels can be found at X, p. 629 K., cf. also X, p. 29 , XIII, p. $116 \mathrm{~K}$.

438, line 2. Read: I durst not venture yt for my Cragge.

438, n. 31. Not Erigena, but Duns Scotus, the "Subtle Doctor" of the Middle Ages.

438, line 9. "recover their health againe." All the indications were present that according to Galenic therapy, would demand blood-letting - a plethora of blood (not "stoutness"), the prime of life, an illness in springtime (when blood predominates among the humours), and toughness and consistency of strength [virium] to withstand venesection.

438, n. 36 . "Spirituale venenum": a poison acting on or like the spirits within the body.

438, line 16. "Latibulis".

438, In quo ... conferunt: "In which case bezoardics [Besoardica], sudorifics lines 17-18. and heart remedies are most beneficial." Bezoardics (antidotes or bezoar stones), because they deflect [declinant] and keep away poison from the heart, which is the vehicle of ethereal and vital spirit [aurae].

438, line 19. "Sudorem".

438 "Finally cardiacs, because they nurture, increase and preserve that lines 20-22. life-giving [vivificum] nectar of blood, the whole life production [vivacitatem] of the original moisture and the flower of the spirits."

Dr. Boss unfortunately fails to realize that this relates to the medieval -The page numbers in these notes refer to Boss's article, op. cit., note 1 above. 


\section{Vivian Nutton}

theory of humours and spirits, in which these, largely Arabic, concoctions were thought to increase the blood, which in the heart provided the vital spirit; to preserve the "radical moisture", whose gradual consumption by innate heat resulted in death; and to nurture the growth of the natural, vital, and psychic spirits within the liver, heart, and brain.

438, line 25 . "at the swords end than". Butler originally wrote "weapons".

438, line 28. "All the collections sentences are Reduced. . . ."

438, line 33. "Nature, it is still to be done . . I I subscribe willingly."

438, line 37. "Capitall" ["error" or "offence"].

438, line 38. "et naturae morem [?] [observare] . . . ." "Better and safer it is to wait and see the habit of his nature and to complete the work it has begun." If "motum" is read, then translate "movement of his nature".

438, n. 40. Translate: "it [i.e. poisonous matter] is to be led." The reference is to Aphorisms I $21=$ IV 168, 11-12L., in the form given by Galen in his commentary ad loc., XVIIB 439-440 K. Although Dr. Boss's rendering is grammatically possible, the subject to be led, according to Galen and subsequent commentators on this university text, is the material, and the place and manner is determined by the body's natural tendency. Nature is already tending in that direction, and requires no leading. The belief shared by Galen and Sydenham that nature should be assisted in cases where nature by herself might fail is here irrelevant, for what is "uncertaine and dowtfull" is not the outcome of a disease but the present condition of the body and its suitability for bleeding. Better to wait for an indication from nature and follow her lead in evacuating noxious material through the skin than rush to bleed and damage an irreparable human body.

438, n. 40. In the margin, in a hurried hand, occur the words "natura medicus, naturae minister est", which, as Dr. Boss shows, can be translated grammatically. Yet the meaning that they give is cryptic, even nonsense -as well say "Dr. $X$ is the servant of $X$ "-and the slightly odd punctuation, together with the caret mark, should give pause for thought. A famous Hippocratic quotation, Epidemics I.II, in the form noted by Galen, XVII A $151 \mathrm{~K}$, and given as such in the forgeries at XV 309 and XVI $305 \mathrm{~K}$, provides the answer: Nature is a healer and "the doctor is the servant of nature". In his hurry to add yet another Hippocratic reference in the margin to be quoted to the King, Butler made the simple error of writing "medicus" once, instead of twice as "Natura medicus, medicus naturae minister est." Alternatively, although much less likely, "natura" in the margin may signify the appropriate place in the text for the insertion of "medicus . . . est".

The idea that the doctor is the servant of healing nature is also used by Paracelsus-the doctor is "der knecht der natur" (I, p. 230, ed. Sudhoff) and also "allein der natur diener" (VII, p. 150, cf.III, p. 71)but originality cannot here be claimed for him. 


\section{Dr. Butler revisited}

438, line 40. Galen: a paraphrase of his commentary on Hippocrates' Aphorisms I.1 =XVIIB, 352-3 K.

439 line 4. The origin of Inscitia loquax, a favourite phrase of Butler's, is questionable. Although the words do not occur in the Vulgate, the sentiment is Jewish, cf. Proverbs 10, 14; 17, 28; the Mishnah, Pirke Aboth, 5.7 (tr. Danby, Oxford 1964, p. 456); and Proverbs 9. 13,

ẻsheth kesiluth hömiyyah

pethayyuth ubhal-yadhcahmah

A woman of folly is loud/boisterous

simplicity and does not know anything,

which may be Butler's source, if he co-ordinated hömuyyah pethayyuth as a means of rectifying a possible corruption at the beginning of line 2 .

In the great compilation of P. Picinelli, Mundus Symbolicus, 2nd ed., Cologne, 1729, XV.251 s.v. vas; XIV.34 s.v. crepitaculum (in both cases quoting the earlier commentaries on scripture of Cornelius a Lapide), the words "ignorans loquax" appear as a marginal heading. Butler might have drawn his motto from a similar earlier work and added the reference to the "Hebrewe tongue" to enhance his own learning. Cf. also for the idea, Erasmus, Adagia, n. 4571 "loquax talpa", ed. Basle 1559, p. $968 .{ }^{20}$

439, line 4. For "igitur" read "ut": "As Cicero says [Rhetorical Divisions 60], showing oneself off is vain ...".

439, line 5. For " $A$ " read " $e t$ "; "And it makes no difference whether one is superior in morals or in age" or "whether the former [ignorance] comes through morals or age." This is not a direct quotation, but may be a careless allusion to Aristotle, Nic. Ethics 7, 1154a, 31-34: it makes no difference whether an evil nature is congenital (aetate) or due to habit (moribus), possibly conflated with Aristotle's doctrine of ignorance due to one's own predilections or (Nic. Ethics VI.12: 1143b, 8) to one's age.

439, n. 45. The poet is Seneca, a favourite of the Elizabethans, in his Thyestes, line 453.

439, n. 46. "May the fortune of the house remain, and generations be counted on generations", a quotation slightly adapted from Vergil, Georgics IV, 209.

439, line 8. The three quotations which form the appendix in the fair copy and whose sources are noted briefly in the rough draft, offer a rare insight into a Renaissance scholar's method of working. Together they illustrate the passing reference in the text to bezoar stones (p. 438, 17-18) and confirm the truth of what might at first appear a rash assertion of their efficacity. According to Butler, congealed "stag's tears" qua bezoardics have certain alexipharmic properties: that they ward off snake-bite by stopping poison reaching the heart is agreed by a range of authorities ancient and modern: to go further and offer a "physiological

so My quest for the origins of this phrase could not have progressed far without the help of Prof. L. W. Forster and the Rev. J. P. M. Sweet. 
reason" would be futile, given contemporary understanding of physiology, and superfluous, since Butler has already said how, on his terms, they act.

According to the draft, the citations from Theomnestus, Avenzoar, Scribonius Largus, and Scaliger come from J. Heurnius' Praxis medicinae nova ratio, book $\mathrm{II},{ }^{21}$ and the fact that the order of the quotations and much of the wording agrees with Heurnius confirms that this relatively modern work was Butler's first source. But there are important differences which prove that he did not stick blindly to it alone, and the page-references in the draft cause difficulty. There they are numbered 126 and 127, but in the first edition of the Praxis, Leyden 1587 , they occur on p. 290; in that of 1590 on p. 335 ; and in the revision of 1609 on p. 245. Butler's numbering, approximately half that of the quarto editions, suggests that the section ran over a page in his copy of the Praxis, which was either of folio size or numbered only on each leaf. Bibliographers may be able to solve this riddle or convict Butler of carelessness in his rough notes.

The first quotation comes largely from Theomnestus, a Greek vet, who describes how "stag's tears" are formed and how they acquire their properties as antidotes: it ends with a reference to Avenzoar's use of them against jaundice. Butler paraphrases Heurnius, omitting a few words, such as the reference to Avenzoar's Liber Teisir (tract I, cap. 6), but keeping the exact order of his source. Butler may be quoting hurriedly [hence "Haly", not "Hazir", for the name of Avenzoar's prince] or from memory or deliberately paraphrasing. If the last, one change is of interest. Heurnius remarks that this antidote is sold at a high price in Asia: Butler alters this to Sicily and the East. Does this reflect contemporary conditions or is it a careless paraphrase?

The other two sections add significantly to Heurnius. In the first he adds an opening sentence, taken, at some remove, from Scribonius Largus, Compositiones, ch. 163, and ends with the observation that these tears are now being offered as bezoardics. ${ }^{22}$ According to the fair copy this comes from Hieronymus Mercurialis, in turn from Scribonius, but although in his Tractatus De Compositione Medicamentorum, Venice, 1590, p. 74, Mercurialis discusses bezoar antidotes,

\footnotetext{
21 On Heurnius, professor at Leyden from 1581 to 1601, see Biographisches Lexikon der hervorragenden Arzte, Berlin, Vienna, Urban \& Schwarzenberg, 1931, vol. 3, p. 205: J. Banga, Geschiedenis van de geneeskunde in Nederland, facsimile reprint of 1868 ed., Schiedam, Interbook International, 1975, pp. 162-180.

${ }^{22}$ The passage is as follows (with the additions bracketed):

[Scribonius Largus scribit In oculis cervorum prope angulos concrescere quasdam lachrymas virosi odoris, quae senescentibus in formam lapidis durantur] Has vero ait Siciliae venatores diligenter colligere easque in Cincto adversus serpentum ictus et morsus gerere: [putoque saepius eventurum ut ostendantur eiusmodi lachrymae, tanquam Bezoardica quaedam medicamenta adversus venena]. Mercurialis ex Scribonio. The previous sentence in Scribonius is: habere ergo in cinctu oportet peucedanum vel cervi, cum captus est, in oculi argulo, qui est ad nares versus, quae inveniuntur sordes virosi odoris.
} 


\section{Dr. Butler revisited}

he gives no reference there to Scribonius. I have, as yet, been unable to discover any closer reference in Mercurialis' writings, and this section may represent Butler's own re-working of ideas from Scribonius, Mercurialis, and Heurnius.

In the draft, this passage is ascribed to Scaliger, p. 175, but that is the page reference in the 1557 edition of the Exotericarum Exercitationum Liber $X V$ to chapter 112, which Butler copies exactly for his final section, doubling the length of Heurnius' quotation: he also adds from ch. 184 Scaliger's etymology of "Bezoar", i.e. "life-preservers". Scaliger claims that stag's tears are found only in stags over a hundred years old, whose tears congeal in the corner of the eye to form a yellow ball, harder than horn, and with small black streaks. While giving an accurate description of the substance, his explanation is even more fanciful than his predecessors": "stag's tears" are no true tears, but a secretion of a sebaceous gland, the lachrymal sinus. ${ }^{23}$ This appendix derives in its conception from Heurnius, but Butler goes beyond him to his source, J. C. Scaliger, and adds other relevant pieces of information to his model. He may be criticized for a lack of imagination or originality, yet in the context of Renaissance medicine this was no condemnation, and Butler was more than a servile copyist.

440. This diagnosis of a patient's vertigo offers a double explanation, first inebriation, and second melancholic vapours resulting in "panges and passions of unquietness and suddeyne anger". The reference to vertigo as a "morbus popularis", common complaint, or loosely, epidemic, does not imply that it is an explanation in itself, as Dr. Boss suggests, but merely that the common symptom or disease of vertigo arises in this patient from an individual and peculiar cause, namely vapours. The first sentence undoubtedly contains a pun, but on two names of adjacent Bedfordshire villages, Potton and Wrestlingworth, and the patient may well have lived near or travelled often to Cambridge by that road. A parallel to the verbal wit of the opening sentences is given by another letter where Butler says, "Surely yowe devysed that Gifte at Tippelstall or Staggerington towne when yowre head was lined with tinkers freese, \& the drunken Truncke of yowre Bodie drowned with nappye and dagger ale."

The Latin quotation, reading "verbera diligentis", is from Proverbs 27.6.

441, line 6. "Salte" need have nothing to do with Paracelsus, but is, according to Galenic theory, one of the characteristics of phlegm or rheume, as fiery is of blood.

441, line 18. "Standynge course of continewaunce" (Cōtin -).

$441, \mathrm{nn} .52$ The opening quotation is from Psalm 119, 71 [118, 71 in the Vulgate], and 53. and the second is from Proverbs 21, 1: "The heart of the king is in the hand of the Lord; he turns it wherever he will."

22 The New Sydenham Society's Lexicon, London, 1881, s.v. Bezoar of deer: cf. also B. Castelli, Lexicon Medicum, Venice, 1795, p. 187, still citing Scaliger as the main authority. 


\title{
Jeffrey Boss
}

441, n. 54. Angariaverunt aegrum: "Have burdened the sick man."

442 , line 6. The right reading is "Impotencye."

442, line 14. The quotation reads:

Omnem crede diem tibi diluxisse supremum.
Grata superveniet quae non sperabitur hora.
Believe that every day which has shone on you has been your last.
Each hour will then come as a pleasure through being unexpected.

The source is Horace Epistles 1.4.14, and is appropriate advice for a condemned man.

These notes confirm that Butler was a typical Elizabethan academic, imbued with the classics and the Bible, but also ready to accept some modern authors and to use practical commonsense in treating his patients. In his theory he was a pragmatic Galenist of the old school, with J. C. Scaliger his favourite among the moderns, and, pace Dr. Boss, in these papers he shows no acquaintance with or liking for Paracelsus and his medicine. He follows Galen's example in treating the individual as a whole, taking into account mental as well as physical factors. ${ }^{24}$ If some of his treatments appeared strange and wonderful to his contemporaries, that too could be said of Galen, and his endeavours to combine in fitting measure both experience and reason follow Galenic precept. Yet throughout he preserves a trenchant independence of judgment, and his vigorous and exuberant style, in controversy and in prescription, proves him beyond doubt a Cambridge character.

s4 S. W. Jackson, 'Galen on mental disorders', J. Hist. behav. Sci., 1969, 5: 365-384.

\section{DR. BUTLER REVISITED: APPRECIATION AND COMMENTS}

\author{
by
}

\section{JEFFREY BOSS*}

The Late Mr. M. Newbold of Cambridge transcribed some of the Clare College papers of William Butler (1535-1618), but the transcriptions were never published. I therefore made transcriptions of eight papers selected for medical interest. ${ }^{1}$ In my copying of the four of these which had transcriptions by Mr. Newbold I was fortunate to be able to use these latter papers as a source of suggestions which, of course, I was not obliged to take. Dr. Nutton's paper now extends this work by

*Jeffrey Boss, Ph.D., M.B., B.S., Wellcome Unit for the History of Medicine, 47 Banbury Road. Oxford OX2 6PE.

1 Jeffrey Boss, 'William Butler (1535-1618): further evidence on a physician between two ages', Med. Hist., 1977, 21 : 434-445. 